УДК 339.5(470:510):614

https://doi.org/10.24866/1813-3274/2020-3/51-67

В. О. Намжилова ${ }^{1}$, Бурятский научный центр СО РАН, г. Улан-Удэ, Россия E-mail: dayavika@yandex.ru

\title{
ПАНОРАМА РОССИЙСКО-КИТАЙСКОЙ ТОРГОВЛИ И ВЛИЯНИЕ ПАНДЕМИИ COVID-19
}

Аннотация. В статье рассматривается динамика развития российскокитайской торговли, расширению которой способствует целый ряд факторов, включая снижение взаимных торговых ограничений, действие антироссийских торговых санкций со стороны западных стран, реализацию совместных проектов в энергетике. Автор отмечает, что при сохранении очевидного приоритета сотрудничества в нефтегазовой сфере идёт работа по диверсификации экспорта в части его неэнергетического сектора, а именно - развития экспортного потенциала отечественного агропромышленного комплекса. Динамичной сферой российско-китайских торговых отношений становится международная торговля услугами, что обусловлено бурным развитием туризма и ростом взаимного коммерческого присутствия. Однако в ситуацию вносит коррективы распространение новой коронавирусной инфекции (COVID-19). Обстановка высокой степени неопределённости в мире, где постепенно большинству стран пришлось прибегнуть к чрезвычайным мерам, закрывая государственные границы, приостанавливая производство, вводя серьёзные ограничения перемещения и тотальный контроль, уже негативно сказалась на ряде направлений двусторонней торговли.

Ключевые слова: российско-китайская торговля, внешнеторговый баланс, структурные сдвиги, активное сальдо, торговля услугами, экспорт энергоносителей, поставки сельхозпродукции, импорт продукции машиностроения, удвоение товарооборота, пандемия COVID-19.

\footnotetext{
${ }^{1}$ Виктория Очировна Намжилова, кандидат экономических наук, научный сотрудник, Бурятский научный центр СО РАН, г. Улан-Удэ, Россия.

Для цитирования: Намжилова В. О. Панорама российско-китайской торговли и влияние пандемии COVID-19 // Азиатско-Тихоокеанский регион: экономика, политика, право. 2020. № 3. С. 51-67. https://doi.org/10.24866/1813-3274/2020-3/51-67.
}

(C) Намжилова В. О., 2020 
Victoria O. Namzhilova ${ }^{1}$, Buryat Scientific Centre of SB RAS, Ulan-Ude, Russia E-mail: dayavika@yandex.ru

\section{PANORAMA OF RUSSIAN-CHINESE TRADE AND THE IMPACT OF THE COVID-19 PANDEMIC}

Abstract. The article examines the dynamics of Russian-Chinese trade development, the expansion of which is facilitated by a number of factors, including the reduction of mutual trade restrictions, the effect of economic sanctions against Russia, and the implementation of joint projects in the energy sector. The author notes that while maintaining the obvious priority of cooperation in the oil and gas sector, work on export diversification has tended in terms of its non-energy sector, namely, to develop the export potential of the domestic agro-industrial complex. Due to the rapid development of tourism and the growth of business activity international trade in services becomes a dynamic sphere of Russian-Chinese trade relations. However, the situation is being corrected by the spread of a new coronavirus infection (COVID-19). The high degree of uncertainty in the world, where gradually most countries had to resort to emergency measures, closing state borders, suspending production, imposing severe restrictions on movement and total control, has already negatively affected a number of areas of bilateral trade.

Keywords: Russian-Chinese trade, foreign trade balance, structural shifts, trade surplus, services trade, energy exports, agricultural supplies, import of mechanical engineering products, mutual trade doubling, the COVID-19 pandemic.

Динамика российско-китайской торговли. Торговые отношения между Россией и Китаем в последние несколько лет отличаются высокой положительной динамикой: внешнеторговый оборот вырос с 59,3 млрд долл. в 2010 г. до 110,9 млрд долл. в 2019 г. Исключением стало сокращение торговли в 2015 г. вследствие падения мировых цен на основной экспортный товар - нефть, а также резкого снижения курса рубля. Расширению торговли в последние годы способствовал целый ряд факторов, включая снижение взаимных торговых ограничений, действие антироссийских торговых санкций со стороны западных стран, успешный запуск экспорта злаков и сельхозпродукции, реализацию совместных проектов в энергетике, а также постепенное замещение европейского импорта китайским. В целом, на фоне

\footnotetext{
${ }^{1}$ Victoria O. Namzhilova, Candidate of Sciences in Economics, Research Fellow, Buryat Scientific Centre of SB RAS, Ulan-Ude, Russia.

For citing: Namzhilova V. O. Panorama of Russian-Chinese trade and the impact of the COVID-19 pandemic // PACIFIC RIM: Economics, Politics, Law. 2020. N 3. P. 51-67. https://doi.org/10.24866/1813-3274/2020-3/51-67.
} 
сокращения торговли России с основными внешнеторговыми партнёрами обоюдная торговля с Китаем растёт и развивается в благоприятных условиях.

Отмечается значительный рост присутствия Китая во внешнеторговых операциях России - с 9,5\% в 2010 г. до 16,6\% в 2019 г. (табл. 1). Китай уже девять лет подряд сохраняет за собой позицию крупнейшего торгового партнёра России, что обусловлено, прежде всего, географическим соседством двух стран и хорошим уровнем двусторонних межгосударственных политических отношений, а также объективной потребностью Китая в ряде товаров российского экспорта [1].

Таблицุа 1

Динамика внешней торговли России с Китаем, 2000-2019 гг.

\begin{tabular}{|c|r|c|c|c|c|c|c|}
\hline Год & $\begin{array}{c}\text { Оборот, } \\
\text { млн долл. }\end{array}$ & $\begin{array}{c}\text { Доля } \\
\text { Китая во } \\
\text { внешней } \\
\text { торговле } \\
\text { России, } \\
\%\end{array}$ & $\begin{array}{c}\text { Экспорт, } \\
\text { млн } \\
\text { долл. }\end{array}$ & $\begin{array}{c}\text { Удельный } \\
\text { вес Китая } \\
\text { в экспорте } \\
\text { России, \% }\end{array}$ & $\begin{array}{c}\text { Импорт, } \\
\text { млн } \\
\text { долл. }\end{array}$ & $\begin{array}{c}\text { Удельный } \\
\text { вес Китая } \\
\text { в импорте } \\
\text { России, \% }\end{array}$ & $\begin{array}{c}\text { Сальдо, } \\
\text { длн } \\
\text { долл. }\end{array}$ \\
\hline 2000 & 6197,0 & 4,5 & 5248,0 & 5,0 & 949,0 & 2,8 & 4299,0 \\
\hline 2005 & 20313,0 & 6,0 & 13048,0 & 5,4 & 7265,0 & 7,3 & 5783,0 \\
\hline 2010 & 59360,7 & 9,5 & 20324,6 & 5,1 & 39036,1 & 17,0 & $-18711,5$ \\
\hline 2011 & 83503,2 & 10,1 & 35241,0 & 6,8 & 48262,2 & 15,8 & $-13021,2$ \\
\hline 2012 & 87571,1 & 10,4 & 35727,2 & 6,8 & 51843,9 & 16,5 & $-16116,7$ \\
\hline 2013 & 88798,5 & 10,5 & 35625,4 & 6,7 & 53173,1 & 16,9 & $-17547,7$ \\
\hline 2014 & 88350,3 & 11,3 & 37494,3 & 7,5 & 50856,0 & 17,7 & $-13361,7$ \\
\hline 2015 & 63553,1 & 12,1 & 28602,3 & 8,3 & 34950,8 & 19,1 & $-6348,5$ \\
\hline 2016 & 66123,2 & 14,1 & 28018,4 & 9,8 & 38104,8 & 20,9 & $-10086,4$ \\
\hline 2017 & 86974,5 & 14,8 & 38918,6 & 10,9 & 48055,9 & 21,1 & $-9137,5$ \\
\hline 2018 & 108244,8 & 15,7 & 56019,4 & 12,5 & 52225,4 & 21,9 & $+3794,0$ \\
\hline 2019 & 110918,5 & 16,6 & 56791,5 & 13,4 & 54127,0 & 22,2 & $+2664,5$ \\
\hline
\end{tabular}

Источник: составлено по данным официального сайта Федеральной таможенной службы Российской Федерации. URL: http://stat.customs.ru/

Расширение экспортных возможностей. За 2010-2019 гг. объёмы экспорта увеличились с 20,3 до 56,8 млрд долл., при этом за долгое время в 2018 г. образовался профицит торгового баланса в размере 3,7 млрд долл., который сохранился и в 2019 г. (2,6 млрд долл.). Формирование активного сальдо стало возможным благодаря росту российского экспорта энергоносителей. По итогам 2019 г. основную долю в российском экспорте в Китай составляют минеральные продукты - более $70 \%$, древесина и целлюлозно-бумажные изделия - более 7\%, продовольствие и сельскохозяйственное сырьё - более 6\%, машины, оборудование, транспортные средства - более 5\%, продукция химической промышленности - более $3 \%$, металлы и изделия из них - более $2 \%$. 
Рост российского экспорта в Китай в последнее десятилетие заметен практически во всех товарных группах, за исключением поставок текстиля и продукции химической промышленности (табл. 2). Тем не менее, движущей силой наращивания экспорта стали поставки нефтепродуктов - рост составил 3,7 раза. Сильные позиции России на этом направлении сохраняются, в первую очередь, за счёт долгосрочных контрактов. Одним из ключевых направлений экспорта российской нефти Китай стал несколько лет назад: этому предшествовал запуск трубопровода «Восточная Сибирь - Тихий океан», а также ряд двусторонних соглашений, самое крупное из которых - договор между «Роснефтью» и CNPC, заключённый в 2013 г. [2]. В начале 2018 г. была официально введена в эксплуатацию вторая ветка российско-китайского нефтепровода Мохэ - Дацин, позволяющая увеличить объём поставок с 15 до 30 млн тонн в год. По итогам 2019 г. Россия поставила рекордные 77,6 млн тонн нефти со средним уровнем поставок в 1,6 млн баррелей в сутки.

Кроме того, учитывая запуск восточного маршрута газопровода «Сила Сибири» в конце 2019 г., по которому газ будет поставляться с Чаяндинского месторождения (запасы 1,2 трлн кубометров) в Якутии, а с 2022 г. - по плану и с Ковыктинского (2,7 трлн кубометров) месторождения в Иркутской области, дальнейший рост экспорта энергоносителей представляется вполне очевидным.

Значимой статьёй экспорта в Китай остаётся древесина (рост за 2010-2019 гг. в стоимостном выражении в 1,5 раза), хотя её удельный вес в общем экспорте снизился с 14 до 7\%. Ключевой проблемой в этом направлении остаётся поиск баланса между соблюдением национальных интересов и извлечением экономической выгоды. Российские власти постепенно вводят заградительные механизмы для экспортёров древесины, стремясь к сокращению вывоза необработанных лесоматериалов и увеличению доли экспорта продукции лесопереработки.

Помимо традиционных сырьевых статей экспорта особое внимание привлекает увеличение объёмов поставок сельскохозяйственной продукции в Китай (рост в 3,4 раза). Россия из года в год расширяет ассортимент продуктов питания, поставляемых на экспорт. Если в 2010 г. российские продовольственные товары были представлены на китайском рынке в основном рыбой (94\%), то в настоящее время на экспорт идут не только водно-биологические ресурсы (53\%), но и различные масла (19\%), соевые бобы $(11 \%)$, шоколадные конфеты (3\%), пшеница (1\%) и другие продукты питания.

Бурный рост поставок российского продовольствия в Китай совпал по времени с раскручиванием американо-китайского торгового конфликта. Это дало наблюдателям повод утверждать, что новые возможности для российских поставщиков появились именно благодаря торговым размолвкам Вашингтона и Пекина. Но работающие в Китае российские поставщики отмечают: утверждение о том, что ускоренный выход российского продовольствия на китайский рынок происходит исключительно благодаря уходу американцев - слишком обобщённое, а в отношении многих товарных позиций попросту неверное [3]. 


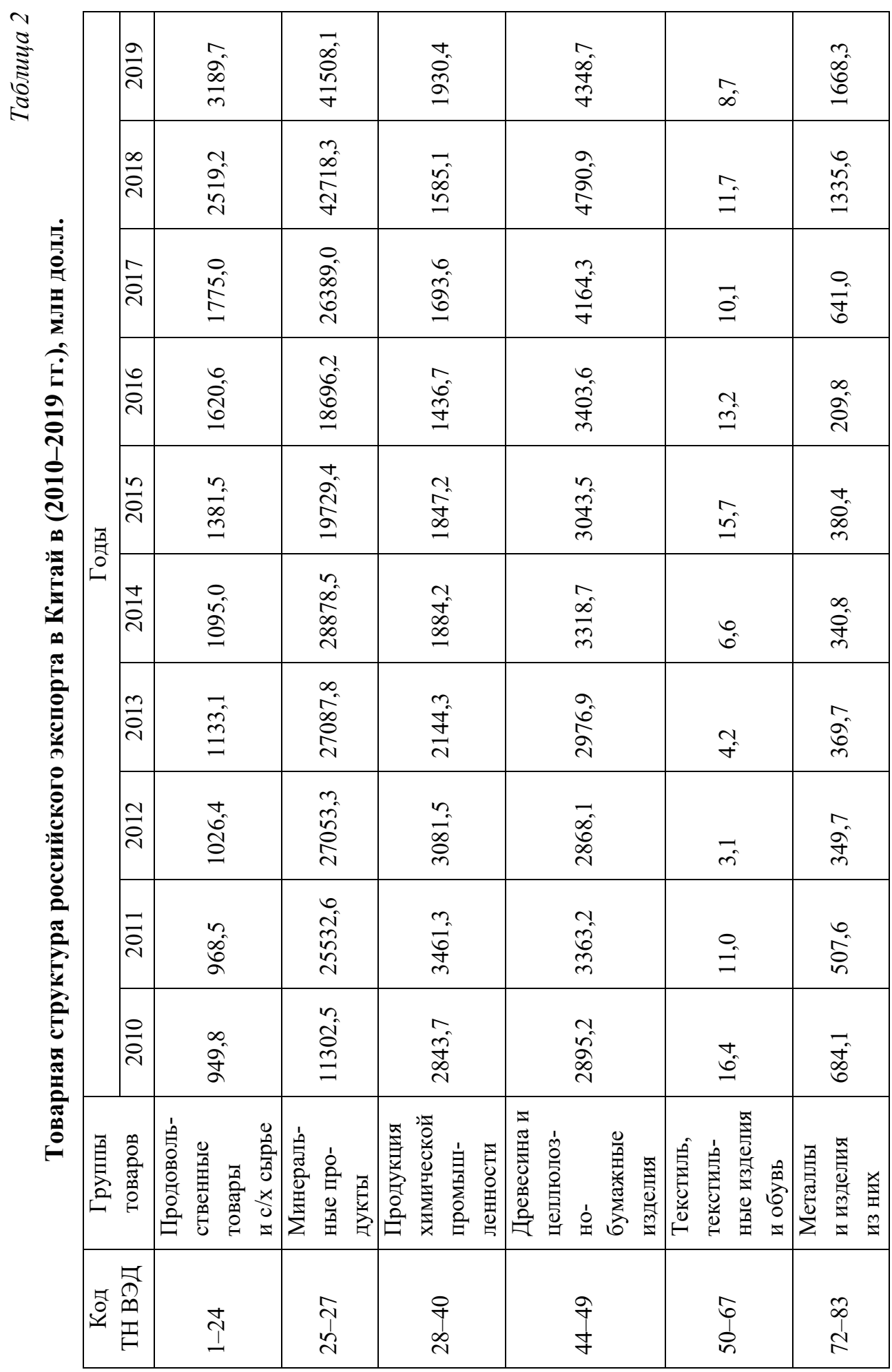




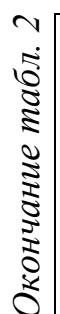

\begin{tabular}{|c|c|c|c|c|}
\hline ते̀ & 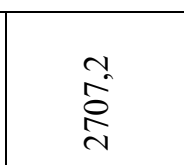 & $\begin{array}{l}0 \\
\infty \\
\infty\end{array}$ & 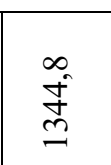 & 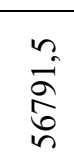 \\
\hline$\stackrel{\infty}{\grave{\sim}}$ & $\begin{array}{l}n \\
\stackrel{\infty}{\infty} \\
\underline{\infty}\end{array}$ & : & $\begin{array}{l}\overline{0} \\
\stackrel{n}{=}\end{array}$ & $\begin{array}{l}m \\
2 \\
\vec{b} \\
\text { n. }\end{array}$ \\
\hline $\overrightarrow{\vec{i}}$ & $\begin{array}{l}\overrightarrow{\mathrm{i}} \\
\overrightarrow{\mathrm{i}}\end{array}$ & 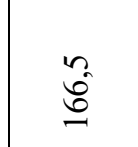 & $\begin{array}{l}0 \\
\dot{\Xi} \\
\end{array}$ & $\begin{array}{l}0 \\
\infty \\
\infty \\
\infty \\
\infty\end{array}$ \\
\hline$\stackrel{\text { i̊ }}{\circ}$ & $\begin{array}{l}0 \\
\text { 我 } \\
\end{array}$ & $\begin{array}{l}\infty \\
\stackrel{+}{I}\end{array}$ & 蒿 & $\begin{array}{l}\stackrel{+}{\infty} \\
\stackrel{\infty}{\vec{D}} \\
\sim\end{array}$ \\
\hline 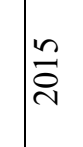 & $\begin{array}{l}\stackrel{t}{\circ} \\
\stackrel{\infty}{\infty}\end{array}$ & 웅 & ${ }_{0}^{3}$ & $\begin{array}{l}\text { m} \\
\hat{\delta} \\
0 \\
\infty \\
i\end{array}$ \\
\hline$\frac{\text { ì }}{4}$ & 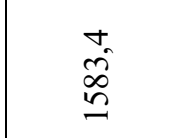 & $\overline{\mathbb{I}}$ & $\frac{0}{m}$ & 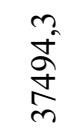 \\
\hline mì & $\begin{array}{l}m \\
\stackrel{n}{n} \\
\stackrel{2}{n}\end{array}$ & $\vec{\alpha}$ & 岁 & 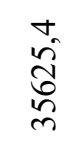 \\
\hline त̄ & $\begin{array}{l}\infty \\
\stackrel{\infty}{\varrho} \\
=\end{array}$ & $\overrightarrow{\vec{\lambda}}$ & $\ddot{0}$ & 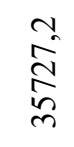 \\
\hline$\overline{\text { సे }}$ & 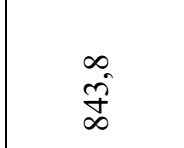 & f & 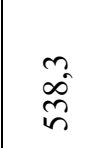 & $\begin{array}{l}\stackrel{0}{*} \\
\vec{i} \\
\tilde{n}\end{array}$ \\
\hline$\stackrel{\circ}{\stackrel{2}{2}}$ & : & $\stackrel{\circ}{\Theta}$ & 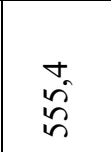 & $\begin{array}{l}\text { tôn } \\
\text { ते } \\
\text { ते }\end{array}$ \\
\hline 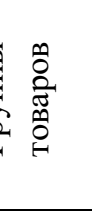 & 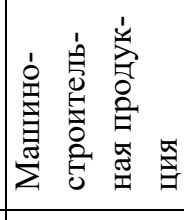 & 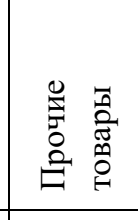 & 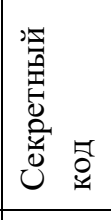 & 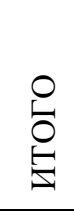 \\
\hline 韋 & $\frac{8}{d}$ & $\begin{array}{lll}f & \vec{f} & \hat{a} \\
\vec{f} & \infty & \frac{a}{\sigma}\end{array}$ & ¿ & \\
\hline
\end{tabular}




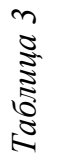

\begin{tabular}{|c|c|c|c|c|c|c|c|c|c|c|c|}
\hline$\frac{\stackrel{\rho}{\sigma}}{\sim}$ & $\begin{array}{l}\text { ปิ } \\
\text { ปิ }\end{array}$ & $\begin{array}{l}\text { å } \\
\text { ㅇ }\end{array}$ & \begin{tabular}{l}
0 \\
2 \\
$\infty$ \\
\multirow{+}{*}{}
\end{tabular} & $\begin{array}{l}\nabla_{n} \\
\underset{+}{\infty}\end{array}$ & $\begin{array}{l}\nabla_{0} \\
\tilde{n} \\
\infty \\
\infty\end{array}$ & $\stackrel{\infty}{\underset{f}{J}}$ & $\stackrel{\sqrt{0}}{\hat{\infty}}$ & $\begin{array}{l}2 \\
\tilde{2} \\
\stackrel{+}{0}\end{array}$ & In & 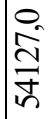 & $\vec{b}$ \\
\hline$\frac{\infty}{\stackrel{\sim}{\sim}}$ & $\stackrel{\circ}{8}$ & గু & $\frac{m}{n}$ & $\begin{array}{l}\text { ○ } \\
\underset{+}{+}\end{array}$ & $\begin{array}{l}\text { ñ } \\
\tilde{\infty} \\
\text { n }\end{array}$ & 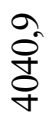 & $\begin{array}{l}\frac{0}{\pi} \\
\infty \\
\stackrel{\curvearrowright}{~}\end{array}$ & $\frac{\hat{v}}{\frac{\tilde{t}}{f}}$ & $\hat{\sigma}^{2}$ & 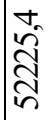 & 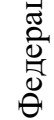 \\
\hline
\end{tabular}

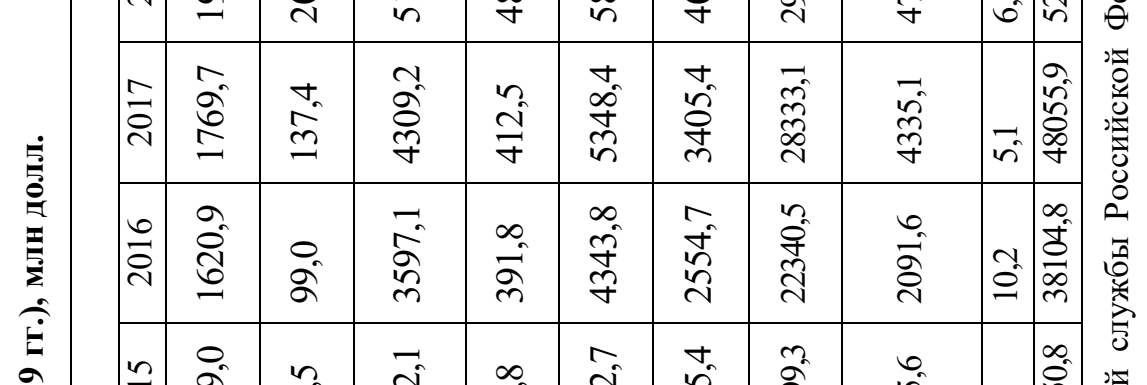

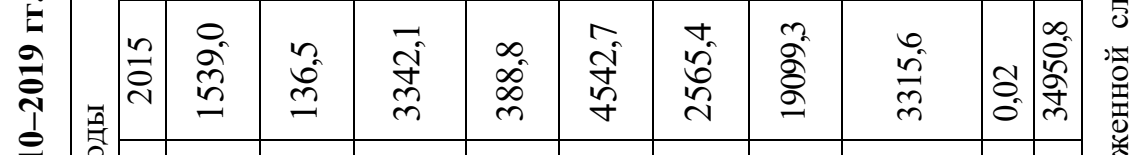

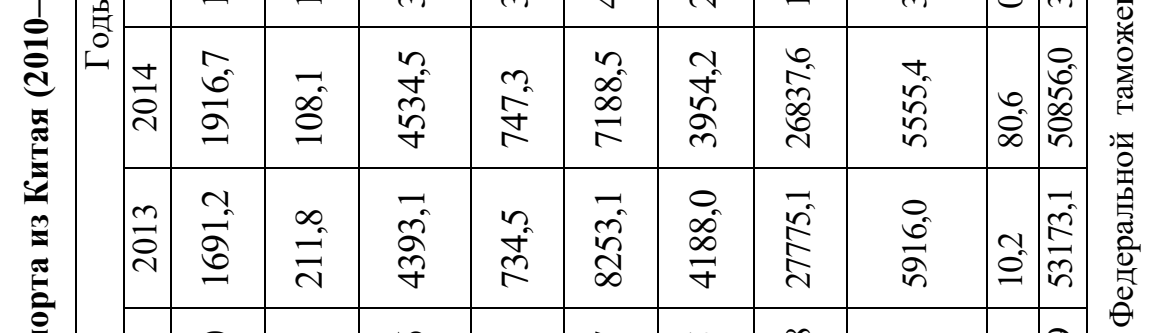

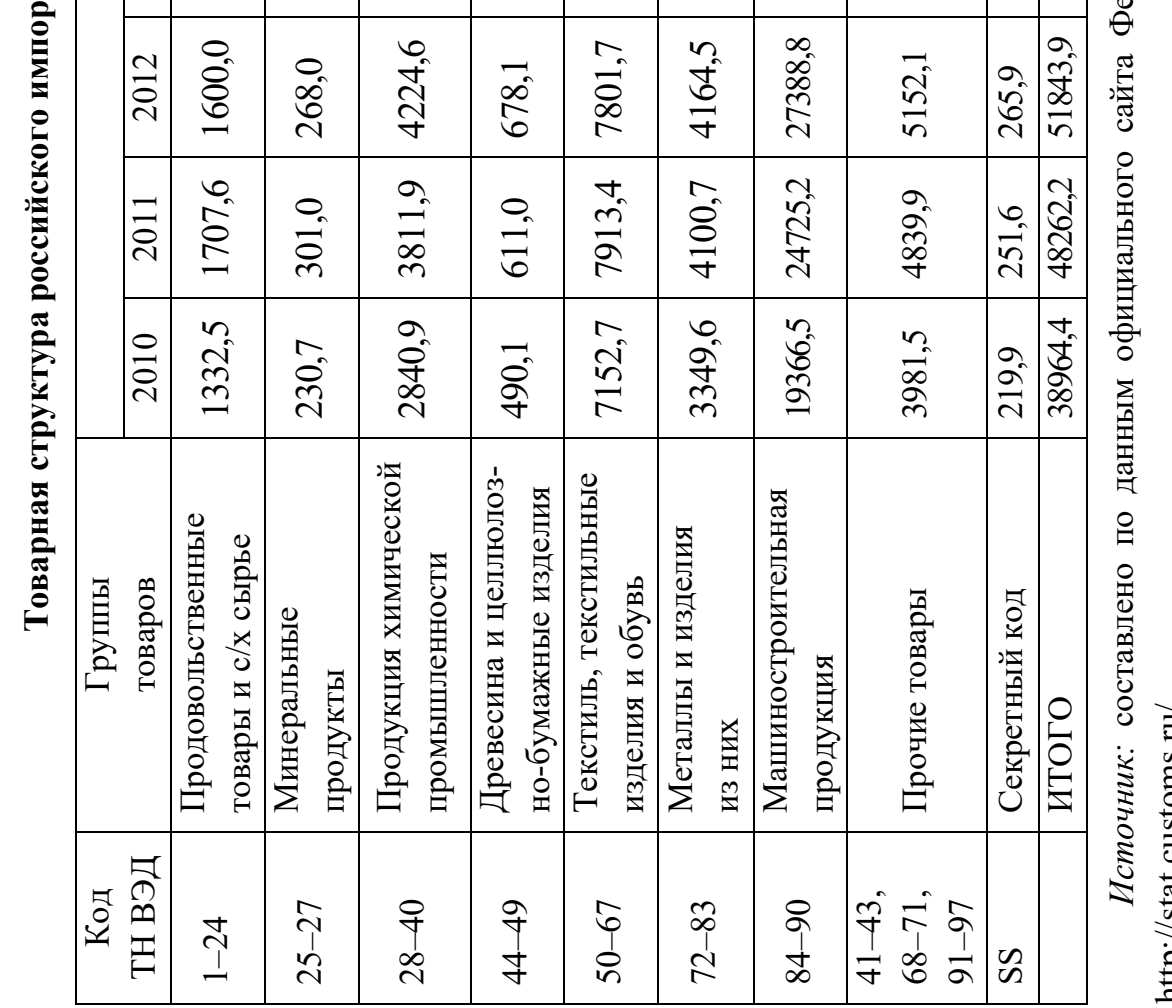


Экспорт продукции агропромышленного комплекса стимулируется государственной поддержкой. Так, для снижения транспортных издержек РЖД и Российским экспортным центром согласовано предоставление 50\%-й скидки на тариф на железнодорожные перевозки для рефрижераторных поездов из Московской и Калужской областей до города Чэнду провинции Сычуань [4].

Растущий потребительский спрос заставляет Китай пересматривать давно действовавшие торговые ограничения на многие продовольственные товары. Так, в феврале 2018 г. Главное государственное управление технического и карантинного контроля за качеством товаров КНР после продолжительных согласований объявило о разрешении импортировать пшеницу из шести регионов России. При этом стороны согласовывают дальнейшую либерализацию экспорта зерновых, а именно отмену регионализации при экспорте пшеницы, ячменя, кукурузы, риса, рапса.

Аналогичные планы по отмене ряда ограничений реализуются в сфере экспорта животноводческой продукции. В 2019 г. Россия получила право экспортировать в Китай замороженное мясо птицы и молочную продукцию [5]. В начале 2020 г. китайской стороной были аттестованы первые российские предприятия для поставок охлаждённой говядины [6]. Продолжается работа по открытию поставок свинины, гороха и круп на китайский рынок.

Импорт товаров из Китая. Структурные сдвиги в импорте китайских товаров (табл. 3) за последние десять лет позволяют выделить две тенденции: рост доли машиностроительной продукции (с 49,7 до 57,0\%) и значительное сокращение импорта текстильной продукции и обуви, как в стоимостном выражении, так и удельного веса данной группы товаров (с 18,3 до 10,8\%). В первом случае определяющую роль сыграло действие санкционной политики западных стран, переориентация российского закупа оборудования и технологий на китайский рынок, особенно учитывая ограниченные условия импортозамещения отечественной продукцией. Во втором случае сокращение импорта текстиля и обуви из Китая происходит ввиду постепенного его замещения продукцией из других азиатских стран, таких как Вьетнам, Малайзия, Пакистан др.

Панорама российско-китайской торговли услугами. Международная торговля услугами представляет собой относительно небольшую, но динамично развивающуюся сферу российско-китайских торговых отношений. По данным Центрального банка РФ, внешняя торговли услугами России с Китаем в 2019 г. составила 7,6 млрд долл. Данный показатель считается довольно низким: по отношению к товарообороту он составляет всего $6,8 \%$, тогда как в среднем внешняя торговля России услугами достигает $23 \%$ внешней торговли товарами. Кроме того, незначительным является присутствие Китая в совокупном внешнеторговом обороте услуг России: доля страны не превышает 4,7\%, хотя в последнее десятилетие имеет тенденцию к росту (табл. 4). В экспорте услуг китайское направление уступает США, Швейцарии, Республике Беларусь, Германии, Великобритании и Казахстану. 
В импорте российских услуг Китай занимает девятое место, уступая Турции, Германии, Кипру, Франции, Ирландии, Великобритании, США и Швейцарии.

Внешнеторговый оборот взаимных услуг России и Китая, долгое время характеризовавшийся отрицательным сальдо в несколько сотен миллионов долларов, с 2017 г. складывается с профицитом, что обусловлено опережающим ростом экспорта услуг. В период 2010-2019 гг. экспорт услуг в Китай вырос в 3,6 раза, с 1081,7 до 3907,2 млн долл. В структуре экспорта услуг по девяти укрупнённым группам (рис. 1) произошли значительные изменения, которые связаны с увеличением доли транспортных услуг и сокращением доли поездок. При этом абсолютные показатели практически всех групп отмечены ростом, а структурные изменения произошли в основном за счёт стремительного роста предоставления транспортных услуг. Если в 2010 г. транспортные услуги для китайских резидентов оказывались в объёме 340 млн долл., то в 2018 г. уже на уровне 1535 млн долл. Иными словами, здесь мы видим отражение бума китайского выездного туризма.

Импорт услуг из Китая отличается стабильным ростом, за исключением посткризисного 2015 г. В целом за 2010-2019 гг. объёмы импортируемых услуг увеличились с 1394,6 до 3651,9 млн долл. Здесь также произошли существенные структурные сдвиги: сокращение доли поездок (с 64,2 до 37,8\%) и опережающий рост по статье «строительство» (с 4,4 до 30,5\%). В настоящее время в импорте услуг из Китая значительную долю занимают прочие деловые услуги $(14,3 \%)$, телекоммуникационные и информационные услуги $(3,1 \%)$, финансовые и страховые услуги $(3,0 \%)$, услуги по техническому обслуживанию и ремонту товаров $(2,8 \%)$, плата за пользование интеллектуальной собственностью (2,2\%). Таким образом, импорт услуг из Китая отличается большей диверсификацией, нежели экспорт, что объясняется расширением китайского коммерческого присутствия в росси йской экономике.

Ориентиры во внешней торговле. По итогам российско-китайских переговоров на высшем уровне и встречи глав правительств России и Китая в Пекине в ноябре 2018 г. поставлена амбициозная задача к 2024 г. вдвое увеличить оборот взаимной торговли. Если в 2018 г. он только преодолел психологически важную отметку в 100 млрд долларов в год, то к 2024 г. будет доведён до 200 млрд долларов. Как отмечают эксперты, для такого удвоения Москве потребуется нарастить объёмы поставок нефти, газа и СПГ, а также «расшить» узкие места транспортной инфраструктуры [4]. Таким образом, основными точками роста двусторонней торговли должны стать расширение торговли энергоносителями, а также такое динамично развивающееся направление, как торговля сельхозпродукцией. По прогнозу Российского экспортного центра, экспорт российского агропромышленного комплекса в Китай вырастет в несколько раз в перспективе пяти лет и составит конкуренцию производителям из Белоруссии, Новой Зеландии и Австралии. 


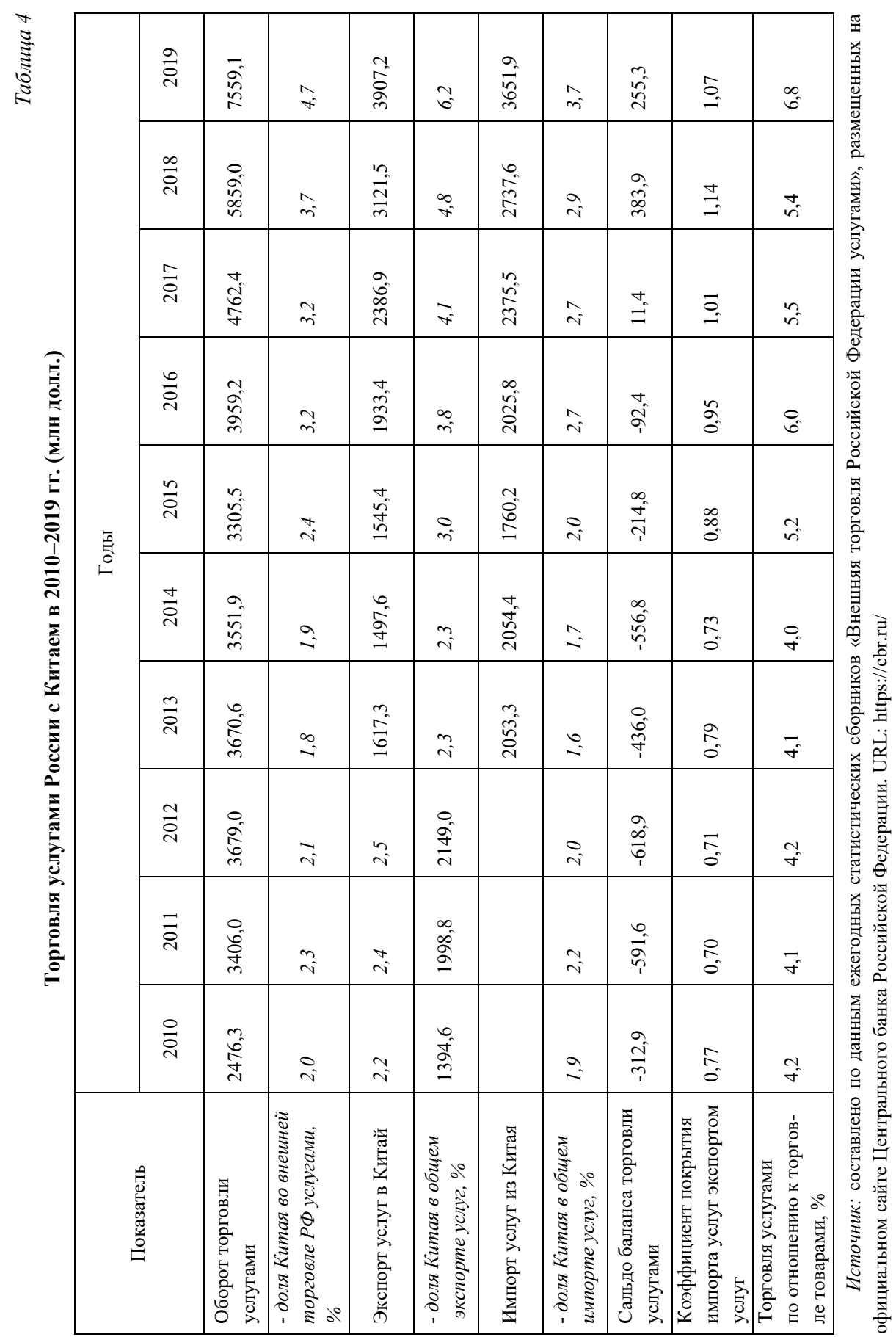




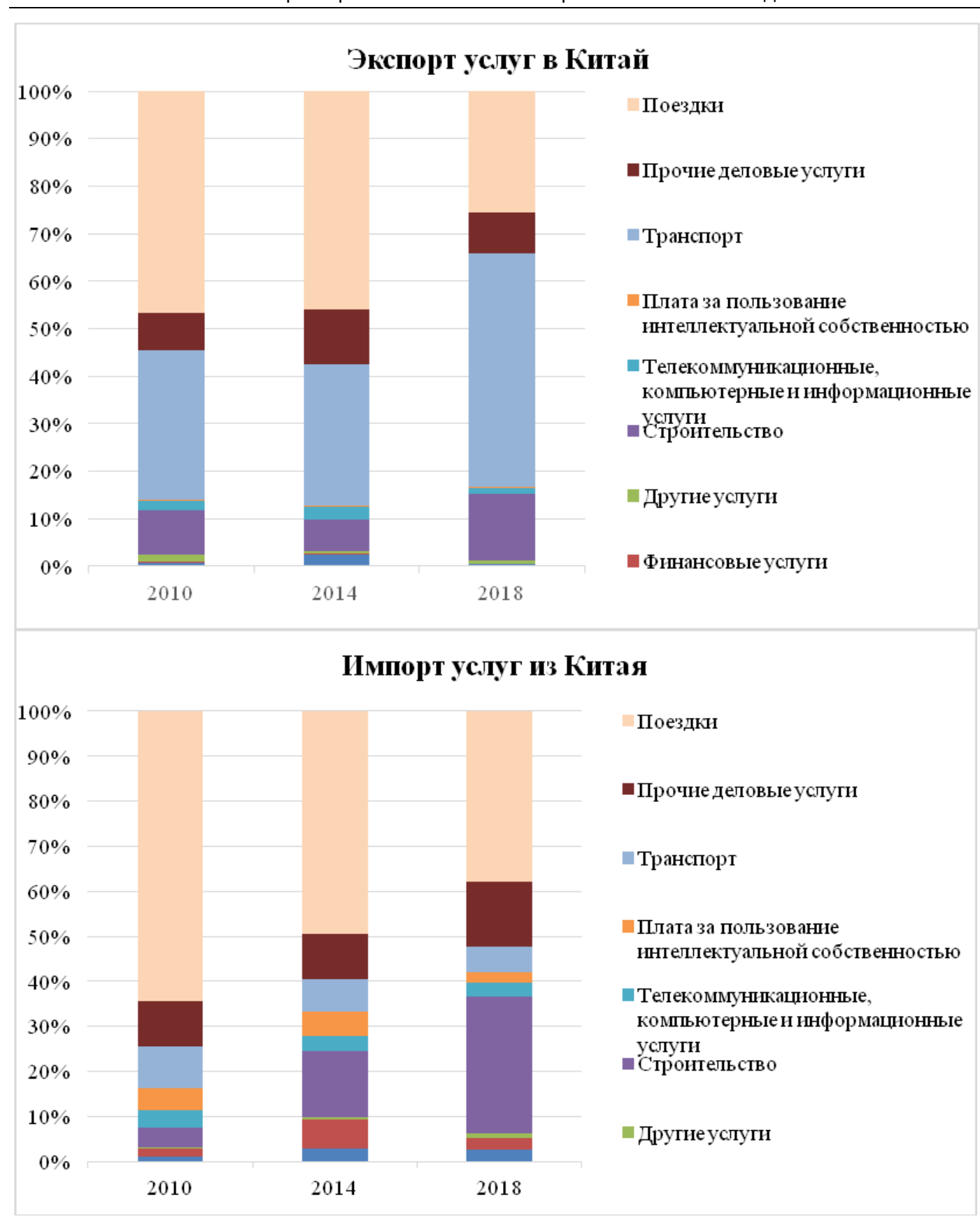

Puc. 1. Структура российско-китайской торговли услугами в 2010-2018 гг.

Источник: составлено по данным ежегодных статистических сборников «Внешняя торговля Российской Федерации услугами», размещённых на официальном сайте Центрального банка Российской Федерации. URL: https://cbr.ru/ 
При стремлении к сбалансированности взаимной торговли целевой ориентир в части российского экспорта в Китай составляет 100 млрд долл. Экспертный анализ и формульные расчеты по методике Международного торгового центра ЮНКТАД/ВТО, проведённые специалистами Всероссийской академии внешней торговли и Всероссийского научно-исследовательского конъюнктурного института, дают оценку потенциала российского экспорта товаров к 2024-2025 гг. в 91,3 млрд долл. Данные расчёты были сделаны с учётом запуска в эксплуатацию Восточного маршрута газопровода «Сила Сибири», реализации проекта «Ямал СПГ», а также ввода в строй Амурского газоперерабатывающего завода. В общей величине вероятного прироста экспорта к 2024-2025 гг. по методике МТЦ свыше 60\% приходится на топливно-минеральные товары, примерно $14 \%$ - на руды, металлы и изделия из них, около 9\% - на химическую продукцию, $8 \%$ - на различные продовольственные товары, 5\% - на лесобумажную продукцию [7].

\section{Влияние пандемии COVID-19 на российско-китайскую торговлю.} Распространение новой коронавирусной инфекции (COVID-19) в начале этого года стало, пожалуй, одним из наиболее непредвиденных обстоятельств в развитии международной торговли во всём мире. Обстановка высокой степени неопределённости в мире, где постепенно большинству стран пришлось прибегнуть к чрезвычайным мерам, закрывая государственные границы, приостанавливая производство, вводя серьёзные ограничения перемещения и тотальный контроль, была охарактеризована как «идеальный шторм» [8].

Первой на сообщения из Китая о COVID-19 отреагировала электронная торговля: в конце прошлого года сократилось количество онлайн-покупок на китайских торговых площадках. Причём негативное влияние оказал именно информационный фон относительно эпидемии: покупатели опасались заражений инфекцией через полученные посылки [9]. Далее воздействие распространявшейся новой коронавирусной инфекции стало ощутимым и в других сферах российскокитайской торговли.

Пандемия COVID-19 спровоцировала рекордное снижение цен на нефть изза обвала спроса на сырьё. Ввиду высокой доли энергоносителей в структуре экспорта цена на нефть оказывает сильное влияние на российско-китайский товарооборот. По итогам первого квартала 2020 г. Россия ожидаемо нарастила темпы экспорта нефти, газа и сжиженного природного газа благодаря новым запущенным проектам «Сила Сибири» и «Ямал СПГ», однако на рынок негативно повлиял тот факт, что в марте этого года страны ОПЕК + не смогли договориться о продлении прежней сделки - новое соглашение по сокращению добычи было принято лишь 1 мая [10]. Эксперты прогнозируют, что под влиянием резкого падения мировых цен на энергоносители показатели обоюдной торговли продемонстрируют сокращение по итогам 2020 г. Избежать драма- 
тичного падения товарооборота представляется возможным с учётом новых проектов в энергетической сфере при стабилизации ценовой динамики на сырьевых площадках в диапазоне 40-50 долл. за баррель [11].

Потери в торговле с начала года отмечаются и у экспортёров леса. Спровоцированный вспышкой коронавирусной инфекции резкий спад производства в Китае привёл к ощутимому снижению спроса на древесину, что, в свою очередь, заметно отразилось на закупочных ценах лесоматериалов. По заявлению Приморской ассоциации лесопромышленников и экспортёров леса, цена за кубометр древесины упала с 200 до 122 долл. [12]. Кроме того, существует большая неопределённость по ранним договоренностям: срыв контрактов возможен ввиду приостановки деловых визитов из-за закрытия государственных границ.

В начале года одним из немногих направлений в обоюдной торговле, демонстрирующих положительную динамику, стал экспорт медицинских изделий: значительная часть российских производителей медицинских защитных масок и костюмов работали только на Китай. Однако угроза дефицита на отечественном рынке вынудила российское правительство ввести временный запрет на вывоз ряда медицинских изделий, включая маски, респираторы, очки, защитные костюмы и пр. [13].

Статистика двусторонней торговли по итогам первого квартала демонстрировала рост объёмов двусторонней торговли на 3,4\%, что выглядело совсем неплохо на фоне сокращения торговли Китая с другими странами. Более того, Россия поднялась в рейтинге внешнеторговых партнёров Китая, оттеснив Бразилию и войдя в первую десятку по товарообороту. Однако стоит отметить, что положительная динамика первого квартала во многом была инерционной. Так, по данным таможенной статистики за январь - июнь 2020 г., торговля с Китаем сократилась на 5,7\%: экспорт упал на $11,6 \%$ до 23,7 млрд долл., импорт вырос на $0,8 \%$ до 24,4 млрд долл.

Наиболее пострадавшей сферой в условиях распространения пандемии COVID-19 становится взаимная торговля услугами. Согласно статистике ЦБР обоюдная торговля услугами сократилась на 15,3\% по итогам первого квартала 2020 г., при этом дальнейшее падение показателей очевидно. Запрет на пересечение государственных границ, продолжительный режим самоизоляции и, в целом, неопределённость будущего сценария развития событий - всё это скажется на ключевых составляющих ещё недавно сулящей хорошие перспективы торговли услугами: сходят на нет туристические поездки, оказание транспортных услуг и услуги строительства.

На этом фоне справедливыми представляются опасения по поводу достижения поставленной цели удвоить двусторонний товарооборот до 200 млрд долларов к 2024 г., поскольку изначально планировалось придерживаться еже- 
годных темпов прироста взаимной торговли на уровне 15\%. Тем не менее, российская сторона не отказывается от ориентира и изъявляет надежду, что влияние пандемии COVID-19 на взаимную торговлю носит временный характер, оставляя многообещающими планы в долгосрочной перспективе [14]. К тому же, определённый оптимизм вселяют антикризисные меры Китая, направленные на восстановление экономики после пандемии [15].

Отмечая перспективы достижения поставленных ориентиров в российскокитайской торговле, специалисты выделяют целую группу факторов, способных существенно скорректировать ожидания: влияние торгово-экономической конфронтации Китая и США, быстрое освоение Китаем собственного выпуска импортируемой продукции, неопределённость динамики и глубины структурных изменений в китайской экономике, последствия развития цифровых технологий, постепенное ужесточение в Китае экологического законодательства и т.д. [7]. Теперь к обозначенным факторам добавилось и влияние пандемии COVID-19: глубину и масштабы её последствий для бесперебойной торговли России и Китая ещё только предстоит оценить.

\section{Список литературы}

1. Островский, А. В. Как нам развивать российско-китайскую торговлю // Современные российско-китайские отношения. - Москва : ДеЛи плюс, 2017. C. 66-81.

2. Каткова, Е. Ставка на чёрное: российская нефть заливает Китай // Газета.ru. - URL: https://www.gazeta.ru/business/2018/02/26/11663455.shtml (дата обращения: 29.08.2020).

3. Щепин, К. Утка по-московски. Российские производители выходят на рынок Поднебесной // Российская газета. - 2019. - 12 сентября. - URL: https://rg.ru/2019/09/12/kak-rossijskie-proizvoditeli-vyhodiat-na-kitajskij-rynok.html (дата обращения: 29.08.2020).

4. Крючкова, Е. Россия и Китай пошли на удвоение / Е. Крючкова, T.0,Едовина // Коммерсант. - 2019. - 18 сентября, № 169. - URL: https:/www.komme rsant.ru/doc/4095545 (дата обращения: 29.08.2020).

5. Щепин, К. Россия - Китай: будем торговать // Российская газета. - 2019. 27 сентября. - URL: https://rg.ru/2019/09/27/rossiia-i-kitaj-udvoiat-tovarooborot-k2024-godu.html (дата обращения: 29.08.2020).

6. Узбекова, А. Россия начинает поставки говядины в Китай // Российская газета. - 2020. - 17 января. - URL: https://rg.ru/2020/01/17/rossiia-nachinaet-postavkigoviadiny-v-kitaj.html (дата обращения: 29.08.2020). 
7. Спартак, А. Н. Современный масштаб российско-китайского торговоэкономического сотрудничества и перспективы удвоения взаимной торговли к 2024 г. // Научные труды Вольного экономического общества России. - 2019. Т. 220, № 6. - С. 83-108.

8. Лукьянов, Ф. Глобальная коррекция // Россия в глобальной политике. 2020. - 19 марта. - URL: https:/globalaffairs.ru/articles/globalnaya-korrekcziya/ (дата обращения: 29.08.2020).

9. «Известия»: количество покупок россиян в Китае в 2019 году сократилось на 7,1\% // TACC. - 2020. - 27 мая. - URL: https://tass.ru/ekonomi ka/8572491 (дата обращения: 29.08.2020).

10. Цены на нефть выросли на фоне вступления в силу новой сделки ОПЕК+ // РИА Новости. - 2020. - 1 мая. - URL: https://ria.ru/20200501/1570848 565.html?rcmd_alg=svd\&rcmd_id=1569423498 (дата обращения: 29.08.2020).

11. У Поднебесной товарооборот со всем миром падает, а с Россией - растёт // Всё о таможне. - 2020. - 10 марта. - URL: https://www.tks.ru/reviews/2020/ 03/10/02 (дата обращения: 29.08.2020).

12. Свинова, Е. Тёмный лес: о новых убытках заявили лесопромышленники ДФО // ИА «Восток России». - 2020. - 10 марта. - URL: https://www.eastruss ia.ru/material/temnyy-les-o-novykh-ubytkakh-zayavili-lesopro myshlenniki-dfo-/ (дата обращения: 29.08.2020).

13. Маски не пускают за границу. Правительство ограничивает экспорт медицинских изделий из-за коронавируса // Коммерсант. - 2020. - 04 марта. - URL: https://www.kommersant.ru/doc/4276347 (дата обращения: 29.08.2020).

14. Российский посол оценил сокращение торговли с Китаем // РИА Новости. - 2020. - 20 мая. - URL: https://ria.ru/20200520/1571708410.html (дата обращения: 29.08.2020).

15. Чем лучше, тем хуже. Александр Габуев о влиянии антикризисной программы Китая на российский ТЭК // Коммерсант. - 2020. - 5 июня. - URL: https://www.kommersant.ru/doc/4366233 (дата обращения: 29.08.2020).

\section{References}

1. Ostrovskii A.V. Kak nam razvivat' rossiisko-kitaiskuyu torgovlyu [How can we develop Russian-Chinese trade]. In: Sovremennye rossiisko-kitaiskie otnosheniya [Modern Russian-Chinese relations]. Moscow: DeLi plyus Publ., 2017, pp. 66-81.

2. Katkova E. Stavka na chernoe: rossiiskaya neft' zalivaet Kitai [Stake on black: Russian oil floods China]. Gazeta.ru. Available at: https://www.gazeta.ru/bus iness/2018/02/26/11663455.shtml (accessed 29 August 2020). 
3. Shchepin K. Utka po-moskovski. Rossiiskie proizvoditeli vykhodyat na rynok Podnebesnoi [Duck in Moscow. Russian manufacturers enter the Chinese market]. Rossiiskaya gazeta, 2019, September12. Available at: https://rg.ru/2019/09 /12/kak-rossijskie-proizvoditeli-vyhodiat-na-kitajskij-rynok.html (accessed 29 August 2020).

4. Kryuchkova E., Edovina T. Rossiya i Kitai poshli na udvoenie [Russia and China went for doubling]. Kommersant, 2019, September 18, no. 169. Available at: https://www.kommersant.ru/doc/4095545 (accessed 29 August 2020).

5. Shchepin K. Rossiya - Kitai: budem torgovat' [Russia - China: we will trade]. Rossiiskaya gazeta, 2019, September 27. Available at: https://rg.ru/2019/09/27/ rossiia-i-kitaj-udvoiat-tovarooborot-k-2024-godu.html (accessed 29 August 2020).

6. Uzbekova A. Rossiya nachinaet postavki govyadiny v Kitai [Russia begins deliveries of beef to China]. Rossiiskaya gazeta, 2020, January 17. Available at: https://rg.ru/2020/01/17/rossiia-nachinaet-postavki-goviadiny-v-kitaj.html (accessed 29 August 2020).

7. Spartak A.N. Sovremennyi masshtab rossiisko-kitaiskogo torgovoekonomicheskogo sotrudnichestva i perspektivy udvoeniya vzaimnoi torgovli k $2024 \mathrm{~g}$. [The modern scale of Russian-Chinese trade and economic cooperation and the prospects for doubling mutual trade by 2024]. Nauchnye trudy Vol'nogo ekonomicheskogo obshchestva Rossii, 2019, vol. 220, no. 6, pp. 83-108.

8. Luk'yanov F. Global'naya korrektsiya [Global correction]. Rossiya v global'noi politike, 2020, March 19. Available at: https://globalaffairs.ru/articles/glo balnaya-korrekcziya/ (accessed 29 August 2020).

9. «Izvestia»: the number of purchases of Russians in China in 2019 decreased by 7.1\%. TASS, 2020, May 27. Available at: https://tass.ru/ekonomika/8572491 (accessed 29 August 2020). (In Russian).

10. Oil prices rose against the backdrop of the entry into force of the new OPEC + deal. RIA Novosti, 2020, May 1. Available at: https://ria.ru/202 00501/1570848565.htm 1?rcmd_alg=svd\&rcmd_id=1569423498 (accessed 29 August 2020). (In Russian).

11. In the Celestial Empire, trade with the whole world is falling, and with Russia - it is growing. All about customs, 2020, March 10. Available at: https://www.tks .ru/reviews/2020/03/10/02 (accessed 29 August 2020). (In Russian).

12. Svinova E. Temnyi les: o novykh ubytkakh zayavili lesopromyshlenniki DFO [Dark Forest: timber merchants of the Far Eastern Federal District announced new losses]. Vostok Rossii, 2020, March 10. Available at: https://www.eastrussia.ru/mate rial/temnyy-les-o-novykh-ubytkakh-zayavili-lesopromyshlenniki-dfo-/ (accessed 29 August 2020). 
13. Masks are not allowed abroad. The government restricts the export of medical devices due to the coronavirus. Kommersant, 2020, March 04. Available at: https://www.kommersant.ru/doc/4276347 (accessed 29 August 2020). (In Russian).

14. The Russian ambassador assessed the decline in trade with China. RIA Novosti, 2020, May 20. Available at: https://ria.ru/20200520/1571708410.html (accessed 29 August 2020). (In Russian).

15. The better the worse. Alexander Gabuev on the impact of China's anti-crisis program on the Russian fuel and energy complex. Kommersant, 2020, June 5. Available at: https://www.kommersant.ru/doc/4366233 (accessed 29 August 2020). (In Russian). 